\title{
Preparing education for the crises of tomorrow: A framework for adaptability
}

\section{Crystal Green ${ }^{1}$ - Laurelyn Mynhier ${ }^{1}$ Jonathan Banfill ${ }^{2}$ - Phillip Edwards ${ }^{1}$. Jungwon $\mathrm{Kim}^{1} \cdot$ Richard Desjardins $^{1}{ }^{\mathbb{C}}$}

Published online: 3 January 2021

(c) UNESCO Institute for Lifelong Learning and Springer Nature B.V. 2021

\begin{abstract}
The COVID-19 crisis has disrupted learning globally, exacerbating regional and global disparities that predated the pandemic. This rupture presents a unique opportunity to reimagine our educational system in times of both calm and crisis. Drawing on the work of political scientist Kathleen Thelen and economist and philosopher Amartya Sen, this article introduces a Framework for adaptability that outlines examples of flexible and equitable adaptation to change. The authors define adaptability as the ability of educational systems to respond to rapidly changing circumstances while maintaining stability, promoting equality, and expanding substantive freedoms and well-being. The key components of educational adaptability are: (1) cooperation, (2) inclusion, and (3) flexibility. This article describes how adaptability in education might be facilitated at individual, community, state and global levels. The authors call attention to a critical need to collectivise our approach to risk at the level of national governance. They suggest that this can be achieved by coordinating various professional, scientific, corporate, community and governmental stakeholders in order to ensure continuity in educational service provision, promoting lifelong learning and overall workforce participation.
\end{abstract}

Keywords Adaptability · Equality · Capabilities · Flexibilisation · COVID-19 · education in crisis

\section{Résumé}

Préparer l'éducation aux crises de demain : un cadre d'adaptabilité - La crise de la COVID-19 a perturbé l'apprentissage partout dans le monde, exacerbant les disparités régionales et mondiales antérieures à la pandémie. Cette rupture offre une occasion unique de réinventer notre système d'éducation tant en période de calme que de crise. S'inspirant des travaux de la politologue Kathleen Thelen et de l'économiste et philosophe Amartya Sen, cet article présente un cadre d'adaptabilité qui esqui-

Crystal Green

crystalbgreen@gmail.com

Extended author information available on the last page of the article 
sse quelques exemples d'adaptation flexible et équitable au changement. Les auteurs définissent l'adaptabilité comme la capacité des systèmes d'éducation à répondre à des situations qui évoluent rapidement et en même temps à maintenir la stabilité, à promouvoir l'égalité et à accroître des libertés et un bien-être essentiels. Les éléments clés de l'adaptabilité éducative sont : (1) la coopération, (2) l'inclusion et (3) la flexibilité. Cet article décrit comment l'adaptabilité pourrait être facilitée dans l'éducation aux niveaux des individus, de la communauté, de l'État et du monde. Ses auteurs attirent l'attention sur le besoin crucial de collectiviser notre approche du risque à l'échelle de la gouvernance nationale. Ils indiquent que l'on peut y parvenir en coordonnant différents acteurs professionnels, scientifiques, entrepreneuriaux, communautaires et gouvernementaux afin d'assurer la continuité de l'offre des services éducatifs, de la promotion de l'apprentissage tout au long de la vie et de la participation générale de la main-d'œuvre.

\section{Introduction}

The COVID-19 crisis has disrupted learning globally, exacerbating regional and global disparities already existing before the onset of the pandemic. The manifestations of this disruption are diverse, ranging from massive deschooling ${ }^{1}$ in some countries to unequal access and heavy reliance on parental efforts in others. The rupture of our educational system as a result of the pandemic has exposed its endemic instability, itself a result of the neoliberal ideology on which the system rests. However, the disruption also presents an unprecedented opportunity to reimagine education on a global scale. Tracing back the sources of instability in the system, it is evident that major forces of social change, including globalisation (Bauman 1998), technology (Bell 2005), and individualisation (Giddens 1991) have interacted with the neoliberal remaking of education to create a precarious system of provision even as regional and international actors have sought to expand and improve it. The marketisation, privatisation and standardisation of schooling have shifted responsibility for the success of education to teachers, families and students, institutionalising exclusionary educational practices in the name of efficiency, academic excellence and national competitiveness. These forces place pressure on the "common" or "public" function of education, insofar as it enhances people's opportunities, life chances, well-being and freedoms, and furthers the establishment of just and equitable societies for all (see Grace 1989). In the near future, further global challenges to educational provision, such as catastrophic climate events, are likely. It is thus critically important to consider how we might promote resilience, continuity and equality in education in times of both calm and crisis.

In this article, we put forth a Framework for adaptability to strengthen the ability of educational systems to respond to rapidly changing circumstances while

\footnotetext{
1 Deschooling refers to "the action or process of removing a child from the school system so as to educate him or her at home; the transitional process undergone by a child removed from the school system" (OUP n.d.-a).
} 
maintaining stability, promoting equality, and expanding substantive freedoms and well-being. The framework supports the "common good" dimension of education, advocating for shared responsibility for financing, provision and governance, for collaborative solutions to common problems, and for the use of educational spaces to foster greater social empathy and global citizenship. We argue for shared educational responsibility based on the principle that the social and economic benefits of education accrue to society at large as well as to the individual, and that the rupture of education therefore represents a risk to us all. COVID-19 has highlighted the degree to which the power of elites is dependent on the marginalised. As such, it offers us a unique moment to call upon elite actors and decision-makers to commit to placing the rights of the many above the needs of the few.

We propose that the key components of educational adaptability are: (1) cooperation, (2) inclusion, and (3) flexibility. Establishing these behaviours as norms creates a virtuous cycle in support of educational resilience, because each component aids the achievement of the remaining components. The article also describes how adaptability in education might be facilitated at the individual, community, state, and global levels, calling attention to the critical need to collectivise risk and responsibility. We argue for a generative approach that provides alternate pathways to education and addresses the unique contexts of communities around the world.

\section{Identifying destabilising trends in education}

Since the 1980s, the rise of neoliberal policymaking has refashioned the educational landscape. Within the neoliberal paradigm, the marketisation of schools was promoted as the most efficient means by which nations could improve student outcomes, enhance growth, and promote national competitiveness (Friedman and Friedman 1980). This belief is grounded in two core neoclassical economic notions. The first is that exposure to unregulated markets allocates resources to their most efficient use (Friedman 1955). The second is that education should be viewed as an investment in human capital in support of a more productive society (Becker 1994). In the education sector this led to privatisation, decentralisation, deregulation, assessment and competition, as well as a shift away from the notion of education as a public good and towards private gain. Although neoliberalism originated in the Global North, recession in the Global South throughout the 1980s resulted in the spread of neoliberal policies there too, embedded in the structural adjustment programmes and educational reforms undertaken by the International Monetary Fund (IMF) and the World Bank (Rizvi 2017; Robertson 2007).

This trend continued in the later decades of the 20th century with the Education for All (EFA) initiative led by the United Nations Educational, Scientific and Cultural Organization (UNESCO) and the push towards global goal-setting, most notably the United Nations Millennium Development Goals (MDGs) to be achieved by 
2015. ${ }^{2}$ This groundbreaking international consensus represented an important step towards the formation of globally accepted human rights and environmental norms. However, due to the continuing influence of neoliberalism, the specific educational investments undertaken by international lending organisations were based on rate of return ${ }^{3}$ modelling whose primary goal was moving individuals out of poverty, rather than promoting social justice, human rights and inclusive educational systems (Jones 1997; Lauglo 1996; Mundy 1998; Torres 2011).

Although the neoliberal focus on education for human capital formation promoted educational investment, it also discounted the social role of education as a common good (Torres 2011; Popkewitz 1991; Apple 1982), fostered a deficit view ${ }^{4}$ of educational gaps (Baldridge 2014; Pitzer 2015), further advantaged wealthy students and families (Giroux 2002), and skirted issues of fairness and opportunity (Barker and Feiner 2004). It thus hindered the potential for education to advance moral and social progress by imbuing values such as tolerance, respect, compassion, empathy and understanding towards the "other" (Desjardins and Schuller 2006). Instead, neoliberalism narrowed the scope of education, making it more about achieving competitive advantage by getting a more prestigious job and enhancing one's social status (Brown 2013). The focus on competition for individual gain fragmented society and reinforced exclusionary practices based on unequal social and power relations (Apple 1993; Ball 2016). These persistent inequalities have been exacerbated as schools rely increasingly on technology, cleaving a "digital divide" between those who have access to computers, tablets and reliable internet and those who do not (Teodoro 2020). Effectively, the neoliberal championing of possessive individualism (Kingfisher 2002; Robertson 2007, also see Macpherson 2010 [1962]) commodified education and skills, trivialising alternate notions of the value of education. This led to instability, lack of cooperation, educational exclusion, and increasing inequality across and within nations, reflected in ever-increasing gaps in wealth, income, educational attainment and socio-economic mobility (Piketty and Goldhammer 2014).

Despite these negative trends, the concerted efforts of social and political elites have ensured that the neoliberal vision of economic and cultural development remains hegemonic (Kwak 2017; Rizvi 2017). In fact, neoliberalism has become so deeply ingrained in the modern socio-political psyche that it is seen as common sense and rarely questioned (Harvey 2005; Tiainen et al. 2019; Torres 2011). We suggest that the pursuit of stable and sustainable educational systems necessitates a new common sense grounded in the collectivisation of risk and shared responsibility, bringing back the principle of education as a public good.

\footnotetext{
2 The Education for All agenda (2000-2015) pursued 8 Millennium Development Goals (MDGs). For more information, visit https://www.un.org/millenniumgoals/ [accessed 25 November 2020].

3 Rate of return refers to "the annual income from an investment expressed as a proportion (usually a percentage) of the original investment" (OUP n.d.-b).

${ }^{4}$ Deficit thinking is "the idea that minority students labor under intellectual handicaps because of their family structure, linguistic background, and culture" (Valencia 2010, p. ix).
} 


\section{Sen, Thelen and the collectivisation of risk}

Our new common sense builds on the work of economist and philosopher Amartya Sen and political scientist Kathleen Thelen. Amartya Sen's work (Sen 1999, $2005,2013)$ provides an ethical grounding from which to consider the relationship between education, individual freedom, equality, and human development. According to Sen,

education makes us the human beings we are. It has major impacts on economic development, on social equity, and gender equity. In all kinds of ways, our lives are transformed by education ... in my judgment [education is] the biggest priority in the world (Husain 2003).

Sen offers a humanistic view of development, highlighting the importance of recognising the suffering of others, the extent to which our behaviour contributes to, or benefits from, the misery of others, and our responsibility as global citizens to improve the human condition, to the extent that that we are able.

In Sen's view, development should consist of the removal of substantial "unfreedoms" that "leave people with little choice and little opportunity of exercising their reasoned agency" in pursuit of the "beings and doings" they have reason to value (Sen 1999, p. xii). In contrast to a narrow definition of development where education is associated with the expansion of productive capacity, Sen argues that "the benefits of education ... exceed its role as human capital in commodity production", both in terms of the benefits that accrue to the individual and those that accrue to society at large (ibid., p. 294). In this understanding of development, education is a key component of freedom, which itself is both the means and the end of development. Access to education is a human right and society shares collective responsibility for its provision (Sen 2013).

In practice, development, including access to education, is enhanced by expanding one's set of choices and agency in determining one's own path (Sen 1999; Robeyns 2005; Drèze and Sen 1995). Since the ability to attend school is mediated by individual and local contexts, which may either expand or contract one's choices (Sen 1999), it is critical that these voices are embedded within a structure that expands educational opportunity and provides individual flexibility. While Sen's work provides a moral grounding for the expansion of one's feasible choices, he stops short of offering the specific means through which this might be accomplished. We therefore draw on the work of Kathleen Thelen (2014), who illustrates a practical means of deploying the state in order to provide holistic and freedom-enhancing educational systems.

Kathleen Thelen's work sets out a practical way to harness the power of the state to create an inclusive and flexible educational system. Thelen argues that capitalism emerges in distinct ways which are mediated by state, labour and corporate interactions in different political regimes (Thelen 2004; Esping-Andersen 1990). She contrasts the political economy of neoliberalism with one of liberalism and social solidarity embedded in flexible and inclusive systems, proposing that the survival of institutions depends upon "active ongoing adaptation to the 
social, political, and market context in which they are embedded" (Thelen 2004, p. 5). Thelen draws on the concept of embedded flexibilisation ${ }^{5}$ to describe how this is achieved. She envisages educational systems that allow society to adapt to changes in the market by providing flexible and diverse educational pathways over the lifespan (i.e. lifelong learning). She argues that subsidising the participation of a broader array of social stakeholders provides systemic stability and reduces the social stigma associated with (re)training by involving society at large in education's success.

An educational system designed this way contrasts with the accelerating process of risk privatisation associated with the neoliberal reformation of education (see also Hacker 2004). Risk privatisation is heightened during times of uncertainty and crisis (Klein 2007; Nadesan 2013). In the context of COVID-19, the lack of collective culpability for the sustainability of education is causing educational systems to collapse. For this reason, we deem collectivisation of risk a key component of our proposed Framework for adaptability. We define collectivisation of risk as the mitigation of individual risk through cooperation and the establishment of collective responsibility for educational provision. Risk is collectivised by creating structures which absorb the risk of exclusion from education and the social exclusion that can result. Successful collectivisation of educational risk requires a shared assessment of mutual vulnerability to external shocks. The state, companies, labour organisations and communities must coordinate their activities in order to attenuate the risk of educational exclusion. Multi-level and multi-stakeholder communication, collaboration and cooperation must be embedded in an integrated system which establishes global, national and local connectivity and shared responsibility.

\section{A framework for individual, community, state and global adaptability}

The primary goals of our proposed Framework for adaptability are to embed resilience in the educational system such that it can spontaneously reconfigure in response to internal or external shocks in times of crisis, and to provide for freedomenhancing lifelong and life-wide education in times of relative calm (Bristow and Healy 2014; Martin and Sunley 2007). Critical elements of the framework include: (1) cooperation, (2) inclusion, and (3) flexibility within and between stakeholders at the individual, community, state and global levels.

Figure 1 provides a visual representation of the overall framework. In the following sections we provide an explanation of the constituent levels and the interactions between cooperation, inclusion and flexibility at the individual, community, state and global levels. The processes of cooperation, inclusion and flexibility are intertwined and recursive within, between and across levels of scale. Although we have separated four levels of scale hierarchically for visualisation purposes, stability

\footnotetext{
5 "Embedded flexibilization ... involves a combination of market-promoting labor-market policies, but combined with social programs designed to ease the adaptation of society, especially its weaker segments, to changes in the market (flexicurity) "(Thelen 2012, p. 147).
} 

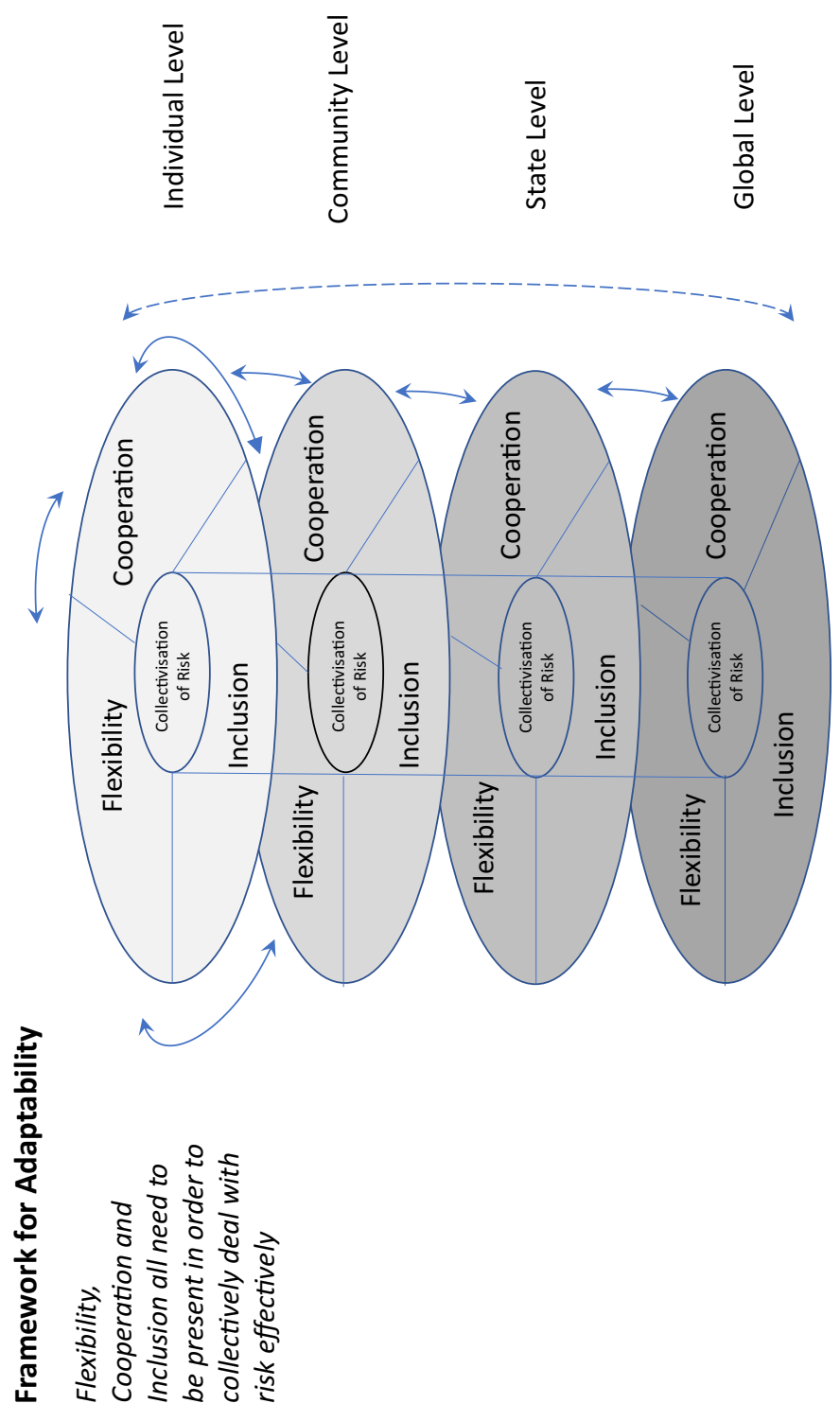

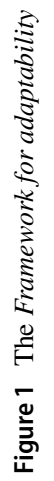




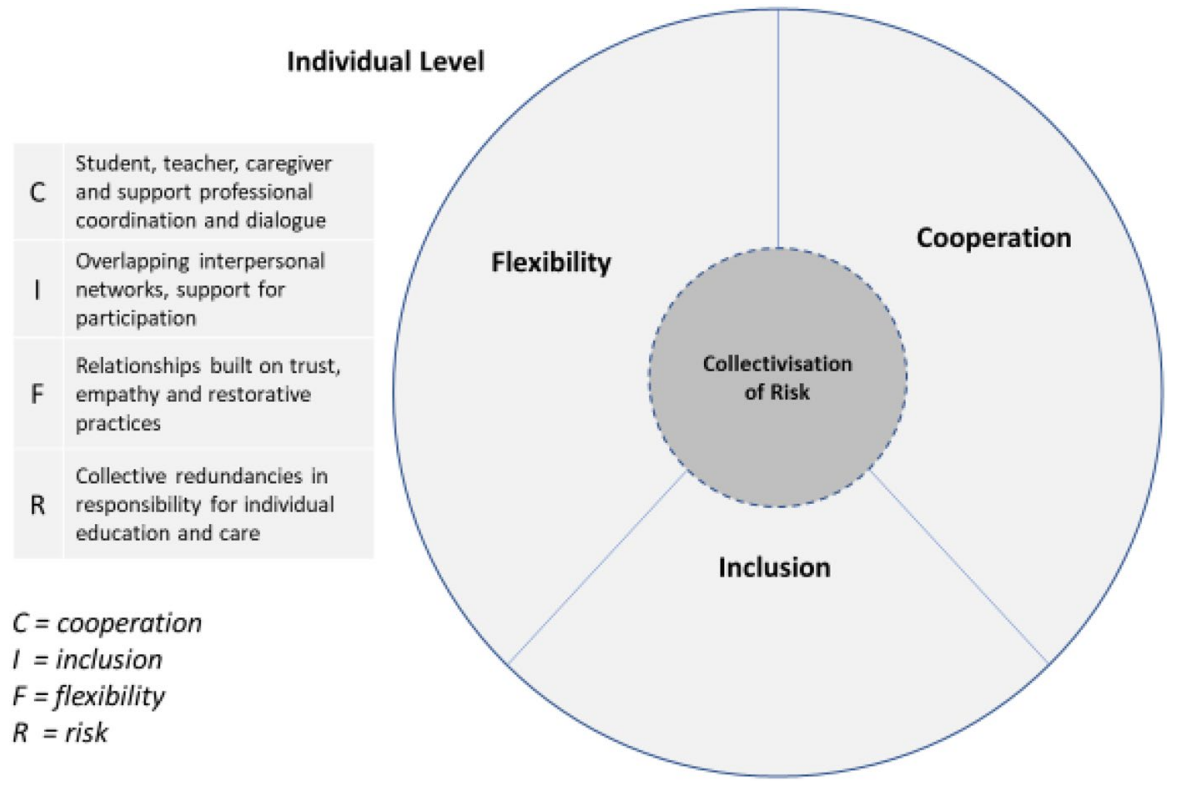

Figure 2 Cross-section of the Framework for adaptability at the individual level

Participatory parity, mutual

C aid; plurality in decisionmaking

Intra- inter-community connectivity, protocols for

I integrating new members into the educational community

Managing learning and

F social-emotional well-being timelines and spaces;

Collective redundancies in

R responsibility for community education and care

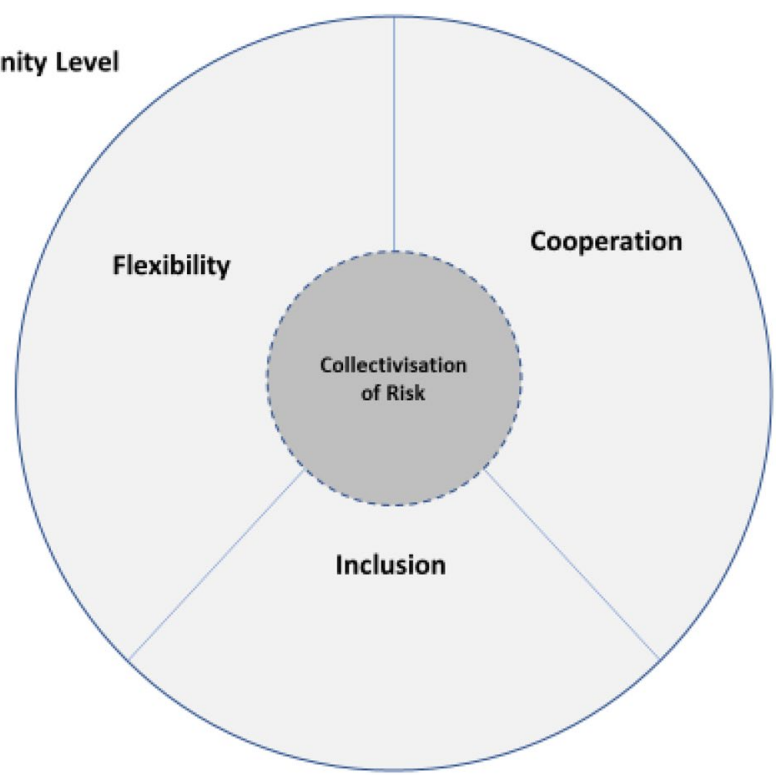

Figure 3 Cross-section of the Framework for adaptability at the community level 


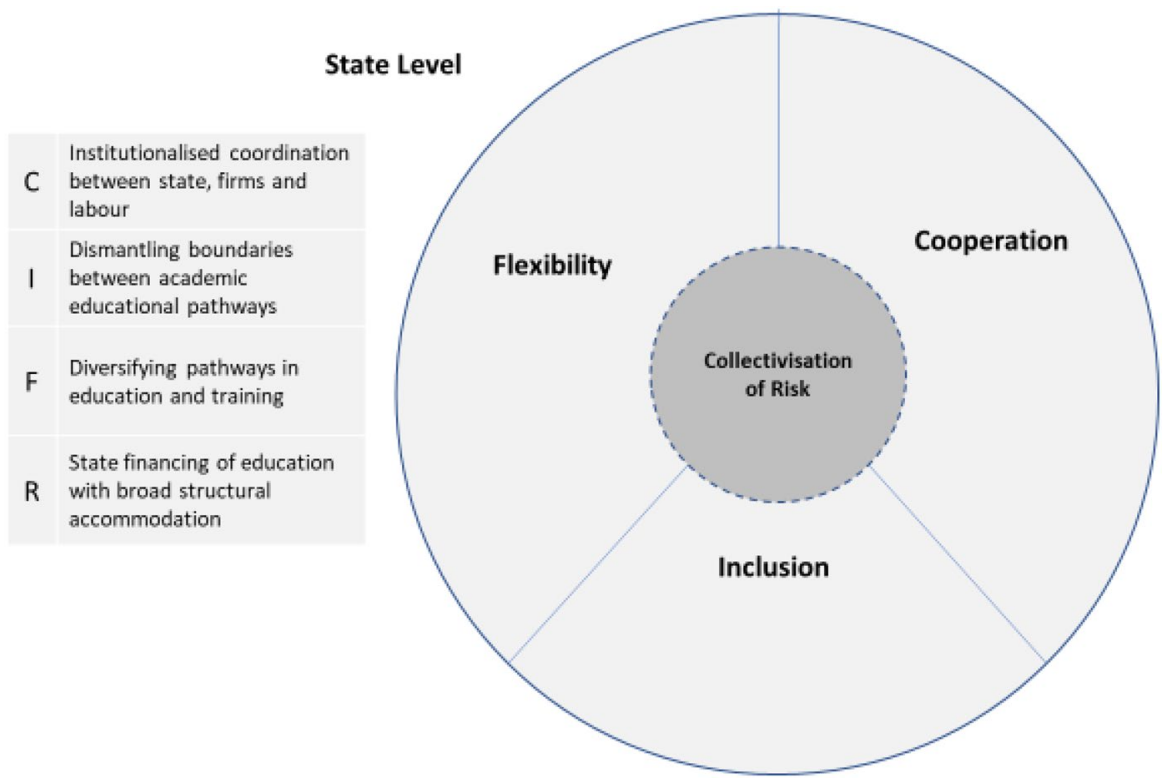

Figure 4 Cross-section of the Framework for adaptability at the state level

Inter-agency, inter-

C governmental and multisectorial coordination

Power-sharing with marginalised actors, multiple and diverse stakeholders,

I including women, youth, black, $\mathrm{POC}$, indigenous, migrant and refugee communities

Room for scrutiny

F Flexible funding and debt forgiveness

Interplay and organisation

$R$ between supra-national authorities to assess and appraise shared risk

\section{Global Level}

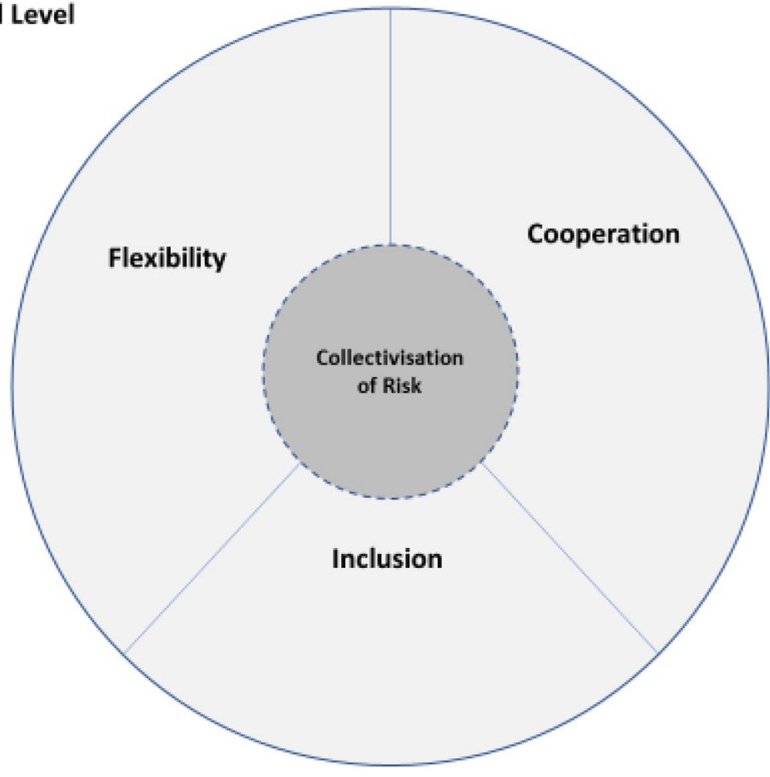

Figure 5 Cross-section of the Framework for adaptability at the global level 
within the system relies on interaction and negotiation between levels. This is indicated by the collectivisation of risk across the framework - from the individual to the global and vice versa - as a core component of systemic support. Figures 2, 3, 4 and 5 illustrate the components at each level.

\section{Individual and interpersonal networks}

Attending to interpersonal relationships and individual contexts is a key component of the Framework for adaptability, which prioritises the needs of individuals within their families, classrooms and communities. At this level, cooperation, inclusion and flexibility are facilitated by complex networks of interpersonal interactions (Figure 2), which are essential for social resilience (Bristow and Healy 2014), and by the provision of educational options that suit individual contexts. Within individual networks, any actor can link to any other actor, who in turn links to third actors through lines of communication, common tasks, agreements or other relationships (ibid.). An open network of connections between actors can help solve educational exclusion by ensuring that the most vulnerable are strengthened by their connections to others. For example, during the current pandemic, teachers in El Salvador, the Dominican Republic and Jamaica are connecting with caregivers and students using WhatsApp, while in Austria school counselling services are available by phone (World Bank 2020). These networks are flexible in that they embed linkages to a more complex set of actors in order to better serve the needs of students.

As well as allowing students to rely on a broader network of individuals, meaningful classroom interactions benefit society at large. The power of the classroom can be harnessed both to support students' individual social and emotional wellbeing and to advance broader social cohesiveness and cooperation. Examples of the former include educators in China taking time to help students understand their own identity and society, and efforts in Singapore to support teachers through professional development (Reimers 2017). As for the latter, curriculum enhancements related to global citizenship can foster respect for diversity, solidarity and a shared sense of humanity (UNESCO 2018).

Expanding interpersonal networks and promoting meaningful interactions at the individual level also fosters educational inclusion by ensuring that students feel valued and fully integrated. This manifests itself in a respectful attitude during dialogue and action, where students value and appreciate one another's contributions (Cooper 2009). Inclusion also manifests itself as recognising when a student or family is absent or struggling and taking shared steps to provide support, through restorative practices which bring students back into a holistic and productive relationship with their community (Carter 2013; Gregory et al. 2016). Individuals engaged in complex and meaningful interpersonal networks are also better connected to the wider local educational and community system. Fostering interpersonal connections strengthens community connections, particularly when efforts are made to bring individuals together in community groups. When multiple paths are available by which education can be entered and re-entered over the lifespan, individuals are better able to 
reintegrate and to benefit from a flexible system which adapts to changes in individual circumstances (Schuller et al. 2004).

Flexibility and inclusion are further enhanced when individuals have access to multiple modalities of education and multiple points of access over a lifetime. Over-reliance on any one modality creates conditions of systemic exclusion and the possibility of educational collapse. In the push to promote the expansion of 21st-century skills and online learning technologies, policymakers have overlooked the fact that "more than 40 per cent of students worldwide have no Internet access at home" (UN 2020). According to data collected by the UNESCO and partners, "nearly 90 per cent of students in sub-Saharan Africa do not have household computers" and "82 per cent are unable to get online" (UN 2020). Even under conditions of 100 per cent connectivity, a severe external shock could wipe out or overburden even the best-laid infrastructure. In response to the COVID-19 crisis, countries are currently scrambling to provide alternative modes of education, such as learning through television and radio (e.g. France, Kenya and Botswana), telephone tutoring (e.g. Nigeria and South Africa) and telephone check-ins between teachers and parents (e.g. the United States), as well as other non-digital and non-electronic means of communication such as workbooks, take-home packets and tactile learning aids (e.g. Vietnam, Brazil) (World Bank 2020; UNICEF 2020). Prioritising global connectivity while simultaneously advancing less technologically dependent options promotes flexibility, inclusion and adaptability.

\section{Educational spaces and community connectivity}

We understand an educational space as the centre of a community. In Western contexts, the school is the typical educational space. However, other informal settings can also serve an educational function, including homes, churches and community centres. Educational spaces facilitate community connectivity (Figure 3), which can enhance adaptability and resilience by bringing individuals into contact with one another. The educational space is a site where identities converge and are contested, and where individuals can share different viewpoints and experiences as members of the community. An educational space is also a place where a community comes together to discuss the meaning and purpose of education. Facilitating positive social interactions within and between diverse groups reduces prejudice, improves social harmony, and contributes to a shared sense of responsibility, purpose and identity (Allport 1954; Brown and Hewstone 2005; Hodson et al. 2018; Pettigrew 1998). We acknowledge that this is not always the case, as interactions between communities can be violent and traumatic (Pratt 1991). Ideally, however, communities reach a consensus about their shared interests and cooperate to provide stable and sustainable education (Mitchell and Sackney 2011; Wickes 2010). The relationship between the community and the educational space is therefore co-constitutional: communities form around educational spaces and/or educational spaces emerge from within communities.

Community cooperation manifests itself in collective mobilisation based on shared aims, negotiated and constructed through generative dialogue (Jäppinen and Sarja 
2012). Community-led processes identify needs, aims and strategies in ways that can be adjusted as circumstances evolve (Ensor et al. 2018; Reid et al. 2009). Within educational communities, cooperation and inclusion manifest themselves as parity in participation and decision making (Fraser 2013). This can provide flexible solutions to the provision of education by creating opportunities for creative problem-solving and sharing of resources between diverse stakeholders. Cooperation between community groups can enhance adaptability by developing culturally and contextually appropriate plans of action that promote equitable and continuous educational provision (Hodson et al. 2018). Continuity of provision during a crisis is most likely to succeed when communities work together to sustain the extra-academic functions of educational spaces (e.g. nutrition, health and childcare). For example, during the COVID-19 crisis, religious communities in Indonesia assisted in promoting rapid educational adaptation by coordinating schools, health facilities, volunteers and clerics (Djalante et al. 2020). Community leaders in China responded cooperatively by buying and delivering groceries and medications to families in lockdown (Wamsley 2020). In the United States (US), volunteer groups provided childcare and financial assistance (Matthew 2020), helping to fulfil in part the role schools typically play as sites for community care and support. These coordinated efforts also help sustain the function of educational spaces as centres of communal well-being.

Strong relationships between professionals, educators, families, community leaders and community members can ensure the continued coordination of schooling and attend to the community's varied needs. However, in today's world, communities and their needs are not static, but change over time in response to social and economic trends. Flexibility and inclusion are therefore enhanced by protocols for welcoming all members into the educational community, and for remaining in contact as community members shift locations. For this to succeed, communities need to develop a sense of solidarity around shared ideas that transcend their differences. This solidarity, however, is exactly what the individualistic neoliberal framework lacks. Instead, it promotes exclusivity within, between and outside of schools, segregating students according to social class or performance. Our vision, in contrast, centres around networks within and between communities that can accommodate diverse identities and educational modalities, thereby enhancing socio-emotional well-being (Hodson et al. 2018; Phalet and Baysu 2020; Zuma 2014). Lastly, it is important to note that strong connections between communities, whether geographical or imaginary, can promote regional solidarity, creating conditions for more productive collective bargaining and coordination with the state. Educational spaces therefore serve as a foundation for greater connectivity across rural, suburban, urban and regional communities. The strength of this connectivity improves collective adaptability and resilience, serving the needs of the many, rather than the few.

\section{The state and the risk of social exclusion}

Having established our view of education as a key component of human development and a fundamental human right, we argue that the state (Figure 4) is responsible for establishing legal and institutional frameworks that prioritise stability, 
equality and continuity in educational provision. In addition, we take the perspective that education is a public good whose social and economic benefits accrue to society as well as to the individual (Grace 1989; Desjardins, forthcoming). Prioritising adaptive educational systems therefore benefits all levels of society by creating a means of sustainable, equitable and inclusive social and economic development. On these grounds, we argue that the state is best suited to bear primary responsibility for reducing risk in education.

Collectivising risk at state level externalises individual financial and structural risk in education. In the most inclusive educational systems, state financing of education is coupled with broad structural accommodation for all, creating systems that are resilient in times of crisis and provide for lifelong and life-wide pathways to education. Resilient and inclusive educational frameworks featuring strong state support, such as those in Sweden and Denmark, promote advanced lifelong learning with high participation rates even among the unemployed, immigrants, older adults, less educated workers and low-skilled adults (Rubenson and Desjardins 2009; Desjardins 2017).

Adaptive educational systems can therefore provide lifelong learning opportunities for all by offering continual opportunities for (re)integration into education and training over the lifespan. When the state, companies and employers cooperate to coordinate educational provision through economic and political coalitions, a more equitable and sustainable education system results. Such a system makes room for education via apprenticeship, for adults as well as young people. Including both the employed and the unemployed in this way is crucial to reducing stigmatisation associated with differentiated training. Denmark's education system provides a good example of this (Thelen 2014). Strong frameworks such as these are critical to inclusion, since they also help reduce stigma associated with social identity categories (e.g. age, language, ethnicity, ability, class). The state can also embed educational flexibility by offering modular training (where students obtain credit for completing small, discrete self-contained units of coursework [see Dejene 2019]) and by allowing students to personalise their training according to their individual preferences. These options can be accessed in times of both calm and crisis. Furthermore, education systems can mitigate the risk of educational exclusion by dismantling traditional boundaries such as vocational vs. academic, initial vs. continuing and youth vs. adult education (Nelson 2010). In short, promoting adaptability, flexibility and inclusion through cooperation at state level attenuates the impact of economic slowdowns by facilitating transitions while protecting all members of society, especially the most vulnerable.

State funding for education represents a political commitment to work towards a just and equitable society where the removal of "unfreedoms" enables citizens to live a life they value (Sen 1999). The state's political commitment to education extends beyond its borders to the global level, reflecting a shared commitment to human rights, peace and sustainability. 


\section{Global coordination for peace and sustainability}

The move towards global goal-setting has established unprecedented levels of shared commitment within the United Nations (UN). Globally shared commitments to education in the MDGs and the Sustainable Development Goals (SDGs) ${ }^{6}$ have served as important benchmarks to guide national policies and the flow of investments. Substantial progress towards global educational parity has been achieved, despite considerable variation in socio-political and economic perspectives (UN 2015). The UN has historically remained a space where views are contested, but on the whole, global peace, diplomacy and cooperation, as the primary mandate of the UN, have prevailed (UN 1945).

Nevertheless, tensions resulting from differing levels of power and privilege between countries remain, and have in many cases been exacerbated by the COVID19 pandemic. In addition to the long-term disproportionate influence of the Global North within the UN's governing bodies and lending institutions, increased reliance in the last 20 years on earmarked donations from private corporations and foundations threatens the UN's multilateral character and undermines democratic global governance:

Private funding runs the risk of turning UN agencies, funds and programmes into contractors for bilateral or public-private projects [where] multilateral mandates become increasingly difficult to carry out, as a profusion of earmarked projects undermines coherence, planning and coordinated action (Seitz and Martens 2017, p. 48).

In the light of these dangers, we argue that, while the UN is uniquely positioned to improve cooperation, inclusion and flexibility by promoting coordination among diverse stakeholders, care should be taken to ensure that these stakeholders really are sufficiently diverse, and that the voices of individuals and local communities are reflected in the UN's educational undertakings. The different levels of the framework for adaptability must be bound into a cohesive system of shared responsibility which does not simply constitute a rubber stamping of educational approaches emanating from the Global North.

For example, donors might be required to develop educational strategies in collaboration with local communities and NGOs, including rural villages, indigenous peoples, migrants and refugees. This would help ensure that negotiated solutions are fit for purpose, that they mitigate the risk of exclusion, that they provide for the continuation of education in the event of a future health, climate, or migration crisis, and that they take into consideration aspects of well-being beyond mere workforce development.

With these caveats in mind, we recognise that educational adaptability at the global level involves cooperation between networks of international actors working

\footnotetext{
${ }^{6}$ Building on the 8 Millennium Development Goals of the EFA agenda (2000-2015), the United Nations 2030 Agenda for Sustainable Development (2015-2030) pursues 17 goals. For more information, visit https://sdgs.un.org/goals [accessed 25 November 2020).
} 
towards a shared commitment to global educational equality. Collaboration between actors from multiple sectors and institutions (e.g. education, health, business) can render systems better prepared to cope with crises, because when information and resources are shared, it is easier to coordinate a rapid and appropriate response. Inclusion is enhanced when open channels of communication are fostered between governments and stakeholders, representing the educational needs of all populations. Open public discourse creates a space to contest and scrutinise those in power, promoting inclusive solutions to educational provision. Collaboration between networks of stakeholders also enhances flexibility. For example, the Global Education Coalition ${ }^{7}$ launched by UNESCO in the wake of the outbreak of the COVID-19 pandemic is bringing together a diverse array of partners, including the International Labour Organization (ILO), the UN High Commission for Refugees (UNHCR), the World Health Organization (WHO), the World Bank, the International Telecommunication Union (ITU), corporate partners such as Microsoft, Google and Facebook, and philanthropic and non-profit organisations, including Khan Academy, Dubai Cares, Profuturo and Sesame Street (UNESCO 2020).

\section{Critical discussion}

The Framework for adaptability presented above outlines an approach to education that promotes resilience at the systemic level. It values mutual caring and dialogue over profit-seeking, precision and standardisation. Adaptability involves modulating educational provision without having to change the entire system and without dissolving into chaos. This capacity at each of the four levels we analyse is critical not only during crises, but also in times of stability. In times of global crisis, children may experience increased vulnerability due to illness and lack of stable housing, food and income, resulting in anxiety and trauma for them and their caregivers (UNICEF 2020). A well-designed system should therefore assure students at all times of adequate nutrition and housing, freedom from violence, access to learning materials, and a means of receiving feedback on their work (see also Nussbaum 2001).

The massive deschooling resulting from measures to curb the spread of COVID19 has shown that adaptability is crucial and that teachers, caregivers and students depend on each other as they work together to address basic needs while also maintaining the provision of education. Unfortunately, most school systems are still subject to an industrial logic of efficiency which does not allow them, or the people within them, to adapt as circumstances change. Whilst national economies have

\footnotetext{
7 The Global Education Coalition is a platform for collaboration and exchange to protect the right to education during the COVID-19 pandemic and beyond. This coalition among more than 140 members from the UN family, civil society, academia and the private sector takes action in four ways (1) Understanding needs on the ground; (2) Cooperating with Ministries of Education and local communities; (3) Leveraging the commitments and strengths of Coalition members; and (4) Implementing impactful solutions. For more information, visit https://globaleducationcoalition.unesco.org/ [accessed 25 November 2020].
} 
shifted over time from agrarian to manufacturing, or from manufacturing to service, education systems have struggled to adapt to hyperconnectivity, information access and inequality at the birth of the 3rd millennium. The forces of neoliberalism, globalisation, technology and individualism have called into question the generally accepted notion that education is a public good, shifting responsibility for its success away from public bodies and onto individuals, teachers and families. If left unchecked, the shocks caused by COVID-19 and other crises of the future are likely to interact with these forces, exacerbating existing problems.

Our proposed Framework for adaptability is not about forming exhaustive or prescriptive tailored learning plans to turn each child into an ideal citizen with a predetermined set of competencies (Lundahl and Brunila 2020). Rather, it places ultimate responsibility for embedding flexibility on the entity responsible for the provision of education as a human right: the state. In this role, the state does not act alone, but in dialogue with a multitude of organisations, institutions and communities. The state represents the public collectively, and as such is responsible for the financial burden of the collective risk of educational disruption. There is still room for market or corporate engagement with education, but it is subordinated to social solidarity through collective organisation.

We propose a turn away from the industrial logic of efficiency, standardisation and perfect communication, towards a biological and metabolic understanding of the natural rhythms of adaptive systems (González de Molina and Toledo 2014; Stein et al. 2019). ${ }^{8}$ Natural systems are resilient because they are responsive to change. They feature intertwining networks of actors and organically self-organising patterns which emerge from local environments and incorporate diversity and redundancy (Mehaffy and Salingaros 2017). In human social systems, adaptability is based on democratic values of dialogue, diversity and open communication. The framework sees the plurality of human experience and meets students where they are, as people who are at once persistent and changing, vulnerable and resilient. The long-term goal will be to nurture a new politics of adaptation which instead of looking back to outdated liberal models opens up "conditions for the possibility of adaptation" and change (Rosa 2017, p. 9). Further work is required to render the framework capable of addressing the complex problems of the future and extending it to encompass additional critical areas and theories, for example climate change and ecopedagogy ${ }^{9}$ (Misiaszek and Torres 2019). The frameworks of the future will need to look beyond the human to create different forms of collaborative "world-making projects", in education and beyond (Tsing 2015).

Crises such as the COVID-19 pandemic offer an opportunity to break with the past and reimagine our shared future. A growing recognition of the failures of neoliberalism over the past 40 years is already evident in economics. Neoliberal ideologies are increasingly being challenged by economic approaches that highlight

\footnotetext{
8 An adaptive system is a complex evolving network of elements capable of self-(re)organisation and transformation in response to its environment.

9 Ecopedagogy is based on Paulo Freire's "pedagogy for transformational actions toward ending socioenvironmental injustices” (Misiaszek and Torres 2019).
} 
sustainability and shared prosperity within the means of the planet, rather than targeting unending growth and reliance on trickle-down effects (Boushey 2019; Davis 2006; Piketty and Goldhammer 2014; Raworth 2017; Stiglitz 2019, 2017). We also see evidence of this shift in the international political commitment to the SDGs, and in the various ways local institutions have found to moderate the market in different contexts, such as those outlined above. In suggesting resistance to the damaging forces of neoliberalism, we do not suggest the erasure of the market. Rather, we stand with those social scientists who question the efficacy of the market in providing and reforming public goods such as education. We argue that excessive marketisation, particularly the marketisation of education and political processes, undermines democracy and fractures society (Stiglitz 2019; Torres 2008). The current scramble to remake education in the wake of COVID-19 reveals a collective appetite for social change. As Arundhati Roy (2020) says, the pandemic is "a portal". Collectively we will choose which ideas we carry with us to build the future.

\section{Conclusion}

This article proposes a Framework for adaptability which defines education as a public good. It argues for shared responsibility for the financing, provision and governance of education, in order to enable the collaboration needed to solve common problems. We have proposed that the collectivisation of risk is a viable mitigating response to the vulnerability exposed and exacerbated by crises, combining three principles: cooperation, inclusion and flexibility. Education is a powerful force for cooperative, inclusive and flexible action, because it enables us to weave together a common fabric across multiple levels of society. The ongoing COVID-19 crisis provides an opportunity to rethink how individuals, communities, nations and our global society can work together to make our educational systems more resilient to global crises.

The ongoing impact of the current pandemic on educational and economic systems worldwide has shown the individualistic neoliberal conception of education to be unsustainable. Modern global connectivity mandates sustainable systems which account for our interdependence and mutual vulnerabilities. It is time to develop new frameworks which connect diverse networks of people and systems, grounded in interpersonal cooperation and inclusion and providing flexible modes and pathways to education. The individualisation of risk, framed as common sense in the predominant neoliberal discourse, is increasingly seen as an ineffective response to common crises. Flexibility is required at the collective level. This will only become more pressing as we move into a future beset with risks and dangers that will continue to threaten education, chief among them climate change. We hope that governments around the world will use the opportunity arising from the experience of the COVID-19 pandemic to reimagine and restructure educational systems, making them more resilient and more freedom-enhancing.

Acknowledgements All authors contributed to the conception of this article. Manuscript drafts were completed by Crystal Green and Laurelyn Mynhier; Philip Edwards contributed literature about the 
"community" section; Jungwon Kim drafted an initial version of the "state" section and drafted parts of the critical discussion; Richard Desjardins drafted the parts of the introduction and the conclusion of the article, and also provided intellectual leadership. Crystal Green, Laurelyn Mynhier and Philip Edwards critically revised the work. Jonathan Banfill synthesised, critically revised and edited the manuscript. All authors commented on previous versions of the manuscript. All authors read and approved the final manuscript.

\section{References}

Allport, G. W. (1954). The nature of prejudice. Cambridge, MA: Addison-Wesley.

Apple, M. W. (1982). Education and power. London/Boston, MA: Routledge and Kegan Paul.

Apple, M. W. (1993). The politics of official knowledge: Does a national curriculum make sense? Discourse, 14(1), 1-16. https://doi.org/10.1080/0159630930140101.

Baldridge, B. J. (2014). Relocating the deficit: Reimagining Black youth in neoliberal times. American Educational Research Journal, 51(3), 440-472. https://doi.org/10.3102/0002831214532514.

Ball, S. J. (2016). Neoliberal education? Confronting the slouching beast. Policy Futures in Education, 14(8), 1046-1059. https://doi.org/10.1177/1478210316664259.

Barker, D. K., \& Feiner, S. F. (2004). Liberating economics: Feminist perspectives on families, work, and globalization. Ann Arbor, MI: University of Michigan Press.

Bauman, Z. (1998). Globalization: The human consequences. New York: Columbia University Press.

Becker, G. (1994). Human capital: A theoretical and empirical analysis, with special reference to education (3rd ed.). London/Chicago, IL: The University of Chicago Press.

Bell, D. (2005). Science, technology and culture. Maidenhead: McGraw-Hill Education.

Boushey, H. (2019). Unbound: How inequality constricts our economy and what we can do about it. Cambridge, MA: Harvard University Press.

Bristow, G., \& Healy, A. (2014). Building resilient regions: Complex adaptive systems and the role of policy intervention. Raumforschung und Raumordnung, 72(2), 93-102. https://doi.org/10.1007/ s13147-014-0280-0.

Brown, P. (2013). Education, opportunity and the prospects for social mobility. British Journal of Sociology of Education, 34(5-6), 678-700. https://doi.org/10.1080/01425692.2013.816036.

Brown, R., \& Hewstone, M. (2005). An integrative theory of intergroup contact. Advances in experimental social psychology, 37(37), 255-343. https://doi.org/10.1016/S0065-2601(05)37005-5.

Carter, C. C. (2013). Restorative practices as formal and informal education. Journal of Peace Education, 10(1), 36-50. https://doi.org/10.1080/17400201.2012.721092.

Cooper, C. W. (2009). Parent involvement, African American mothers, and the politics of educational care. Equity \& Excellence in Education, 42(4), 379-394. https://doi.org/10.1080/106656809032283 89.

Davis, J. (2006). The turn in economics: neoclassical dominance to mainstream pluralism? Journal of Institutional Economics, 2(1), 1-20. https://doi.org/10.1017/S1744137405000263.

Djalante, R., Lassa, J., Setiamarga, D., Mahfud, C., Sudjatma, A., Indrawan, M., Haryanto, B., Mahfud, C., Sinapoy, M.S., Djalante, S., Rafliana, I., Gunawan, L.A., Surtiari, G.A.K., \& Warsilah, H, (2020). Review and analysis of current responses to COVID-19 in Indonesia: Period of January to March 2020. Progress in Disaster Science, 6, Art. 100091. https://doi.org/10.1016/j.pdisa s.2020.100091.

Dejene, W. (2019). The practice of modularized curriculum in higher education institution: Active learning and continuous assessment in focus. Cogent Education, 6(1), Art. 1611052. https://doi. org/10.1080/2331186X.2019.1611052.

Desjardins, R. (2017). The political economy of adult learning systems. London: Bloomsbury.

Desjardins, R. (forthcoming). The political economy of education. Unpublished manuscript, forthcoming in R. Arnove, C.A. Torres, \& L. Misiaszek, L. (Eds), Comparative Education: The dialectic of the global and the local (5th edn). Lanham, MD: Rowman \& Littlefield.

Desjardins, R., \& Schuller, T. (2006). Measuring the effects of education on health and civic engagement: Proceedings of the Copenhagen symposium. Paris:: Organisation for Economic Co-operation and Development (OECD), Centre for Educational Research and Innovation (CERI). Retrieved 25 November 2020 from http://www.oecd.org/education/innovation-education/37437718.pdf. 
Drèze, J., \& Sen, A. (1995). India: Economic development and social opportunity. New Delhi: Oxford University Press.

Ensor, J. E., Park, S. E., Attwood, S. J., Kaminski, A. M., \& Johnson, J. E. (2018). Can communitybased adaptation increase resilience? Climate and Development, 10(2), 134-151. https://doi. org/10.1080/17565529.2016.1223595.

Esping-Andersen, G. (1990). The three worlds of welfare capitalism. Princeton, NJ: Princeton University Press.

Friedman, M. (1955). The role of government in education. New Brunswick, NJ: Rutgers University Press.

Friedman, M., \& Friedman, R. D. (1980). Free to choose: A personal statement. New York: Penguin Books.

Fraser, N. (2013). Fortunes of feminism: From state-managed capitalism to neoliberal crisis. London: Verso.

Giddens, A. (1991). Modernity and self-identity: Self and society in the late modern age. Stanford, CA: Stanford University Press.

Giroux, H. (2002). Neoliberalism, corporate culture, and the promise of higher education: The university as a democratic public sphere. Harvard Educational Review, 72(4), 425-464. https://doi. org/10.17763/haer.72.4.0515nr62324n71p1.

González de Molina, M., \& Toledo, V. M. (2014). The social metabolism: A socio-ecological theory of historical change. Cham: Springer International Publishing.

Grace, G. (1989). Education: commodity or public good? British Journal of Educational Studies, 37(3), 207-221. https://doi.org/10.1080/00071005.1989.9973812.

Gregory, A., Clawson, K., Davis, A., \& Gerewitz, J. (2016). The promise of restorative practices to transform teacher-student relationships and achieve equity in school discipline. Journal of Educational and Psychological Consultation, 26(4), 325-353. https://doi.org/10.1080/10474412.2014.929950.

Hacker, J. S. (2004). Privatizing risk without privatizing the welfare state: The hidden politics of social policy retrenchment in the United States. American Political Science Review, 98(2), 243-260. https ://doi.org/10.1017/S0003055404001121.

Harvey, D. (2005). A brief history of neoliberalism. Oxford: Oxford University Press.

Hodson, G., Crisp, R. J., Meleady, R., \& Earle, M. (2018). Intergroup contact as an agent of cognitive liberalization. Perspectives on Psychological Science, 13(5), 523-548. https://doi.org/10.1177/17456 91617752324.

Husain, M. (2003). Interview: Amartya Sen. PBS Wide Angle: Time for School series, 4 September [TV video recording and transcript]. Arlington, VA: Public Broadcasting Service (PBS). Retrieved 25 November 2020 from https://www.pbs.org/wnet/wideangle/interactives-extras/interviews/time-forschoolinterview-amartya-sen/1477/.

Jäppinen, A. K., \& Sarja, A. (2012). Distributed pedagogical leadership and generative dialogue in educational nodes. Management in Education, 26(2), 64-72. https://doi.org/10.1177/089202061142998 3.

Jones, P. W. (1997). On world bank education financing. Comparative Education, 33(1), 117-129. https:// doi.org/10.1080/03050069728677.

Kingfisher, C. (2002). Introduction: The global feminization of poverty. In C. Kingfisher (Ed.), Western welfare in decline: Globalization and women's poverty (pp. 3-12). Philadelphia, PA: University of Pennsylvania Press.

Klein, N. (2007). The shock doctrine: The rise of disaster capitalism. New York: Metropolitan Books.

Kwak, J. (2017). Economism: Bad economics and the rise of inequality. New York: Pantheon Books.

Lauglo, J. (1996). Banking on education and the uses of research. A critique of: World Bank priorities and strategies for education. International Journal of Educational Development, 16(3), 221-233. https://doi.org/10.1016/0738-0593(96)00015-6.

Lundahl, L., \& Brunila, K. (2020). Silences and challenges. In K. Brunila \& L. Lundah (Eds), Youth on the move: Tendencies and tensions in youth policies and practices (pp. 185-190). Helsinki: Helsinki University Press. https://doi.org/10.33134/HUP-3.

Martin, R., \& Sunley, P. (2007). Complexity thinking and evolutionary economic geography. Journal of Economic Geography, 7(5), 573-601. https://doi.org/10.1093/jeg/lbm019.

Matthew, Z. (2020). "Solidarity not charity": How L.A.'s "Mutual aid" groups are creating community during a crisis. Los Angeles Magazine, 3 April [online article]. Retrieved 25 November 2020 from https://www.lamag.com/citythinkblog/mutual-aid-covid/ 
Macpherson, C.B. (2010 [1962]). The political theory of possessive individualism: Hobbes to Locke. North York, ON: Oxford University Press Canada.

Mehaffy, M., \& Salingaros, N. A. (2017). Design for a living planet: Settlement, science, \& the human future. Portland, OR: Sustasis Press.

Misiaszek, G. W., \& Torres, C. A. (2019). Ecopedagogy: The missing chapter of Pedagogy of the Oppressed. In C. A. Torres (Ed.), The Wiley handbook of Paulo Freire (pp. 463-488). Hoboken, NJ: John Wiley \& Sons Inc.

Mitchell, C., \& Sackney, L. (2011). Profound improvement: Building capacity for a learning community (2nd ed.). Abingdon: Routledge.

Mundy, K. (1998). Educational Multilateralism and World (Dis)Order. Comparative Education Review, 42(4), 448-478. https://doi.org/10.1086/447523.

Nadesan, M. (2013). Fukushima and the privatization of risk. Basingstoke: Palgrave Macmillan.

Nelson, M. (2010). The adjustment of national education systems to a knowledge-based economy: A new approach. Comparative Education, 46(4), 463-486. https://doi.org/10.1080/03050068.2010.519480.

Nussbaum, M.C. (2001). Women and human development: The capabilities approach Cambridge: Cambridge University Press.

OUP (Oxford University Press) (n.d.-a). Deschooling. In Lexico.com [online dictionary]. Detroit, MI: Lexico.com. Retrieved 24 November 2020 from https://www.lexico.com/definition/deschooling.

OUP (n.d.-b). Rate of return, In Lexico.com [online dictionary]. Detroit, MI: Lexico.com. Retrieved 25 November 2020 from https://www.lexico.com/definition/rate_of_return.

Pettigrew, T. F. (1998). Intergroup contact theory. Annual review of psychology, 49(1), 65-85. https://doi. org/10.1146/annurev.psych.49.1.65.

Phalet, K., \& Baysu, G. (2020). Fitting in: How the intergroup context shapes minority acculturation and achievement. European Review of Social Psychology, 31(1), 1-39. https://doi.org/10.1080/10463 283.2020.1711627.

Piketty, T., \& Goldhammer, A. (2014). Capital in the 21st century. Cambridge MA: The Belknap Press of Harvard University Press.

Pitzer, H. (2015). Urban teachers engaging in critical talk: Navigating deficit discourse and neoliberal logics. Journal of Educational Controversy, 9(1), Art. 8. https://cedar.wwu.edu/jec/vol9/iss1/8.

Popkewitz, T. S. (1991). A political sociology of educational reform: Power/knowledge in teaching, teacher education, and research. New York: Teachers College Press.

Pratt, M. L. (1991). Arts of the contact zone. Profession (1991), 33-40. https://www.jstor.org/stabl $\mathrm{e} / 25595469$.

Raworth, K. (2017). Donut economics. White River Junction, VT: Chelsea Green Publishing.

Reid, H., Alam, M., Berger, R., Cannon, T., Huq, S., \& Milligan, A. (2009). Community-based adaptation to climate change: An overview. Participatory learning and action, 60(1), 11-33.

Reimers, F. (Ed.). (2017). One student at a time: Leading the global education movement. North Charleston, SC: CreateSpace Independent Publishing Platform.

Rizvi, F. (2017). Globalization and the neoliberal imaginary of educational reform. Education Research and Foresight Working Papers, no. 20. Paris: UNESCO. Retrieved 25 November 2020 from https:// unesdoc.unesco.org/ark:/48223/pf0000247328.

Robertson, S.L. (2007). "Remaking the world": Neo-liberalism and the transformation of education and teachers' labour. Bristol: Centre for Globalisation, Education and Societies, University of Bristol. Retrieved 25 November 2020 from http://www.bris.ac.uk/education/people/academicStaff/edslr/ publications $/ 17 \mathrm{slr}$.

Robeyns, I. (2005). The capability approach: A theoretical survey. Journal of Human Development, 6(1), 93-114. https://doi.org/10.1080/146498805200034266.

Rosa, H. (2017). Adaptation, not fossilization: Two responses to the refugee crisis. Eurozine. [online article]. Retrieved 25 November 2020 from .https://www.eurozine.com/adaptation-not-fossilization/.

Roy, A. (2020). The pandemic as a portal. Financial Times, 3 April [online article]. Retrieved 25 November 2020 from https://www.ft.com/content/10d8f5e8-74eb-11ea-95fe-fcd274e920ca.

Rubenson, K., \& Desjardins, R. (2009). The impact of welfare state regimes on barriers to participation in adult education: A bounded agency model. Adult Education Quarterly, 59(3), 187-207. https:// doi.org/10.1177/0741713609331548.

Schuller, T., Preston, J., Hammond, C., Brasset-Grundy, A., \& Bynner, J. (2004). The benefits of learning: The impact of education on health, family life and social capital. London: Routledge Falmer.

Seitz, K., \& Martens, J. (2017). Philanthrolateralism: Private funding and corporate influence in the United Nations. Global Policy, 8(5), 46-50. https://doi.org/10.1111/1758-5899.12448. 
Sen, A. (1999). Development as freedom. New York: Knopf.

Sen, A. (2005). Human rights and capabilities. Journal of Human Development, 6(2), 151-166. https ://doi.org/10.1080/14649880500120491.

Sen, A. (2013). The ends and means of sustainability. Journal of Human Development and Capabilities, 14(1), 6-20. https://doi.org/10.1080/19452829.2012.747492.

Stein, S., Andreotti, V., \& Suša, R. (2019). Pluralizing frameworks for global ethics in the internationalization of higher education in Canada. Canadian Journal of Higher Education/Revue canadienne d'enseignement supérieur, 49(1), 22-46. https://doi.org/10.7202/1060822ar.

Stiglitz, J. E. (2017). Globalization and its discontents revisited: Anti-globalization in the era of Trump. New York: W.W. Norton and Company.

Stiglitz, J.E. (2019). The end of neoliberalism and the rebirth of history. Project Syndicate, 4 November [online article] Retrieved 25 November 2020 from https://www.project-syndicate.org/comme ntary/end-of-neoliberalism-unfettered-markets-fail-by-joseph-e-stiglitz-2019-11 .

Teodoro, A. (2020). Contesting the global development of sustainable and inclusive education: Education reform and the challenges of neoliberal globalization. New York: Routledge.

Thelen, K. (2004). How institutions evolve: The political economy of skills in Germany, Britain, the United States, and Japan. Cambridge: Cambridge University Press.

Thelen, K. (2012). Varieties of capitalism: Trajectories of liberalization and the new politics of social solidarity. Annual Review of Political Science, 15, 137-159. https://doi.org/10.1146/annurevpolisci-070110-122959.

Thelen, K. (2014). Varieties of liberalization and the new politics of social solidarity. Cambridge: Cambridge University Press.

Tiainen, K., Leiviskä, A., \& Brunila, K. (2019). Democratic education for hope: Contesting the neoliberal common sense. Studies in Philosophy and Education, 38(6), 641-655. https://doi. org/10.1007/s11217-019-09647-2.

Torres, C. A. (2008). Education and neoliberal globalization. New York: Routledge.

Torres, C. A. (2011). Public universities and the neoliberal common sense: Seven iconoclastic theses. International Studies in Sociology of Education, 21(3), 177-197. https://doi.org/10.1080/09620 214.2011.616340.

Tsing, A. L. (2015). The mushroom at the end of the world: On the possibility of life in capitalist ruins. Princeton, NJ: Princeton University Press.

UN (United Nations) (1945). Charter of the United Nations and Statute of the International Court of Justice. San Francisco: United Nations. Retrieved 25 November 2020 from https://treaties. un.org/doc/publication/ctc/uncharter.pdf.

UN (2015). The Millennium Development Goals report. New York: UN. Retrieved 5 November 2020 from http://mdgs.un.org/unsd/mdg/Resources/Static/Products/Progress2015/English2015.pdf

UN (2020). Startling disparities in digital learning emerge as COVID-19 spreads: UN News, 21 April [webnews]. New York: UN. Retrieved 25 November 2020 from https://news.un.org/en/story /2020/04/1062232.

UNESCO (United Nations Educational, Scientific and Cultural Organization) (2018). Global citizenship education: Taking it local. UNESCO, 18 October [webnews]. Paris: UNESCO. Retrieved 25 November 2020 from https://en.unesco.org/news/global-citizenship-education-taking-it-local.

UNESCO (2020). UNESCO rallies international organizations, civil society and private sector partners in a broad Coalition to ensure \#LearningNeverStops. UNESCO, 26 March [webnews]. Paris: UNESCO. Retrieved 25 November 2020 from https://en.unesco.org/news/unesco-rallies-inter national-organizations-civil-society-and-private-sector-partners-broad.

UNICEF (United Nations Children's Fund) (2020). UNICEF Global COVID-19 Situation Report No. 3. New York: UNICEF. Retrieved 25 November 2020 from https://www.unicef.org/mena/media /8406/file/UNICEF\%20Global\%20CoViD-19\%20Situation\%20Report\%20No.\%203\%20-\%20 1-15\%20April\%202020.pdf\%20.pdf.

Valencia, R. R. (2010). Dismantling contemporary deficit thinking: Educational thought and practice. New York/London: Routledge.

Wamsley L. (2020) Life during coronavirus: What different countries are doing to stop the spread. National Public Radio (NPR) Goats and Soda, 10 March [blog post]. Retrieved 25 November 2020 from https://www.npr.org/sections/goatsandsoda/2020/03/10/813794446/life-during-coron aviruswhat-different-countries-are-doing-to-stop-the-spread. 
Wickes, R. L. (2010). Generating action and responding to local issues: Collective efficacy in context. Australian \& New Zealand Journal of Criminology, 43(3), 423-443. https://doi.org/10.1375/ acri.43.3.423.

World Bank (2020). How countries are using edtech (including online learning, radio, television, texting) to support access to remote learning during the COVID-19 pandemic [dedicated webpage]. Washington, DC: World Bank. Retrieved 25 November 2020 from https:/www.worldbank.org/en/ topic/edutech/brief/how-countries-are-using-edtech-to-support-remote-learning-during-the-covid -19-pandemic.

Zuma, B. (2014). Contact theory and the concept of prejudice: Metaphysical and moral explorations and an epistemological question. Theory \& Psychology, 24(1), 40-57. https://doi.org/10.1177/09593 54313517023 .

Publisher's Note Springer Nature remains neutral with regard to jurisdictional claims in published maps and institutional affiliations.

Crystal Green is a Postdoctoral Scholar in the Social Sciences and Comparative Education Division of the Department of Education at the University of California, Los Angeles (UCLA). Her appointment is funded by the Finnish Cultural Foundation. Her current research relates to the development of teacher education.

Laurelyn Mynhier is a doctoral student at the University of California, Los Angeles (UCLA). She holds a BA, an MA and a PhD (ABD) in economics and has 12 years of economics teaching experience. She has engaged in public and private sector work for the Department of Health and Human Services and the banking industry. Her research interests include international education, gender equality, welfare and development.

Jonathan Banfill is an Assistant Professor of Interdisciplinary Studies at Champlain College in Burlington, Vermont. With a background in Comparative and International Education, his research focuses on developing pedagogies for learning from and engaging with global cities that draw from emerging fields in the New Humanities.

Phillip Edwards is currently pursuing a PhD in international comparative education at the University of California, Los Angeles (UCLA). His focus is in transformational forces, power mechanisms and thematic education history. He has worked in public education for $10+$ years in special and general education at K-Adult Transition levels.

Jungwon Kim is currently pursuing her doctoral studies at the University of California, Los Angeles (UCLA), specialising in international comparative education. She is interested in alternative education and adult learning, and in the relationship between education policy/practice and broader socio-economic and cultural contexts.

Richard Desjardins is Professor of Education and Political Economy at the University of California, Los Angeles (UCLA). He has been involved for over 15 years in education policy analysis related to education governance and provision structures, educational access and participation, learning outcomes and the impact of learning on economy and society. 


\section{Affiliations}

Crystal Green ${ }^{1} \mathbb{D} \cdot$ Laurelyn Mynhier $^{1} \cdot$ Jonathan Banfill ${ }^{2} \mathbb{D} \cdot$ Phillip Edwards $^{1}$. Jungwon $\mathrm{Kim}^{1} \cdot$ Richard Desjardins $^{1}$ (D)

Laurelyn Mynhier

lmynhier@ucla.edu

Jonathan Banfill

jbanfill@champlain.edu

Phillip Edwards

phillipedwards@ucla.edu

Jungwon Kim

jungwonkim86@gmail.com

Richard Desjardins

desjardins@ucla.edu

1 University of California Los Angeles, Los Angeles, CA, USA

2 Champlain College, Burlington, VT, USA 